\title{
Gestational Trophoblastic Disease: an Analysis Focused on Social Determinants of Health
}

Iarlla Silva Ferreira ${ }^{1}$, Sâmua Kelen Mendes de Lima', Juliana Alves Moralles Dias ${ }^{1}$, Linicarla Fabiole de Souza Gomes ${ }^{1}$, Ana Fátima Carvalho Fernandes ${ }^{1}$, Ana Kelve de Castro Damasceno ${ }^{1}$, Mônica Oliveira Batista Oriá1 ${ }^{1}$ Régia Christina Moura Barbosa Castro ${ }^{1}$

\section{Abstract}

Background: Cancer causes are varied and interrelated. It can be internal to the body, related to genetic aspects or external to the body which relates to the environment and living habits, as well as social disparities in which individuals are inserted. By realizing that social stratification exposes individuals to different risks, and therefore to a higher or lower vulnerability, which is directly related to the social context in which the individual is inserted, this study aims to understand the relationship between the social determinants of health and Gestational trophoblastic disease, according to the conceptual framework of Dahlgren and Whitehead.

Methods: A descriptive study whose population was comprised of the medical records of women diagnosed with GTD. It was held in an obstetrical clinic of a Brazilian Northeast maternity of reference. The period was from June to August 2015. 119 medical records of women with GTD were identified between the years 2012-2013. To understand the relationship between the SDH and the factors related to GTD it was adopted the conceptual framework of Dahlgren and Whitehead.

Findings: For each layer of the framework was made a correlation with the data found among the woman. About the first layer it was observed that the prevalence of GTD cases occurred among women aged between 13 and 19, corresponding to $49.9 \%(n=59)$ of the women analysed. Related to the second layer, it was found that there was prevalence of oral contraceptive use with $32.8 \%(n=39)$ of cases. The marital status that prevailed among women was single with $42 \%(n=50)$. About the third layer it was not provided information
1 Federal University of Ceará, Fortaleza, CE, Brazil.

Contact information:

Mônica Oliveira Batista Oriá.

Address: Rua Alexandre Barauna, 1115. Rodolfo Teófilo. Fortaleza, Ceará, Brazil. Tel: +55853366 8456 .

$\equiv$ monica.oria@ufc.br 
related to social and community networks on the medical records. According to the fourth layer, the prevalent education level was less than 8 years of study (48.7\%). Regarding to occupation, $38.7 \%$ ( $=46$ ) of women were housewives. Related to the salary, 6.7\% (n $=8$ ) of women indicated have up to 1 minimum wage as income. Most women live on the countryside (60.5\%). Related to the fifth layer it was found on the literature the need of intersectorial actions to solve the health inequities to promote an appropriate enviroment of health.

Conclusion: It is understood that GTD has multifactorial etiology. Despite of the major influence of the genetic factor, the influence of social determinants on health outcomes of these women cannot be neglected. Therefore, it is essential for health professionals to understand the individuals in their entirety considering the various aspects that involve their lives.

\author{
Keywords \\ Health Social Determinants; \\ Gestational Trophoblastic \\ Neoplasms; Health Care \\ Inequalities.
}

\section{Introduction}

Cancer is the nomenclature used for more than 100 diseases that have in common the uncontrolled growth of cells that invade tissues and organs [1]. Among the various types of cancer, there is gestational trophoblastic disease (GTD) which is a term that covers all tumours involving the placental tissue [2].

Cancer causes are varied and interrelated. It can be internal to the body, related to genetic aspects or external which relate to the environment and living habits, as well as social disparities in which individuals are inserted, that interfere with access to primary prevention, early diagnosis, recommended treatment and rehabilitation $[1,3]$.

The actions of Health Promotion (HP) which aim to improve the quality of life are defined as empowerment of people and communities to modify the social determinants of health (SDH), which represent the social, economic, cultural, ethnic-racial, psychological, behavioural and environmental factors that influence the health-disease process [4].
However, these do not relate simply as cause and effect [5].

The National Committee of Social Determinants of Health adopted the model of Dahlgren and Whitehead [6] to explain the relationship between the levels of the SDH and the health status of the population. This one aims to explain how the different social conditions affect the production of health inequalities $[7,8]$. The SDH model addresses in five layers, according to the level of coverage from the most proximal layer that includes individual characteristics to the most distal layer which depicts the macro determinants $[8,9]$.

By realizing that social stratification exposes individuals to different risks, and therefore to a higher or lower vulnerability, which is directly related to the social context in which the individual is inserted, this study aims to understand the relationship between the social determinants of health and Gestational trophoblastic disease, according to the conceptual framework of Dahlgren and Whitehead. 


\section{Methods}

This is a descriptive study enrolling a sample of 119 medical records of women diagnosed enrolling a sample of 119 medical records of women diagnosed with GTD identified between the years 2012-2013. The data included: sociodemographic and gynaecological-obstetrical data; data related to clinical aspects of the disease and data relating to the data for the post-molar outpatient follow up. The study was approved by the Ethics and Research Committee (\#1121575).

For this study were reviewed all the results and conducted a secondary analysis of data, by organizing the variables according to the social determinants of health based on the conceptual framework of Dahlgren and Whitehead [6]. In spite of existing other more complex models, this was chosen because of its simplicity and easy understanding by several public as well as the graphical display of the various determinants [9].

The model highlights the importance that non clinical factors have on the health status of the individual and the population [7]. The framework starts addressing the characteristics of individuals that influence their potential and their health conditions. The next layer refers to behaviour and individual lifestyles, such as access to information, possibilities of access to food and leisure facilities. Subsequently,

Figure 1: Model of the conceptual framework of Dahlgren and Whitehead.

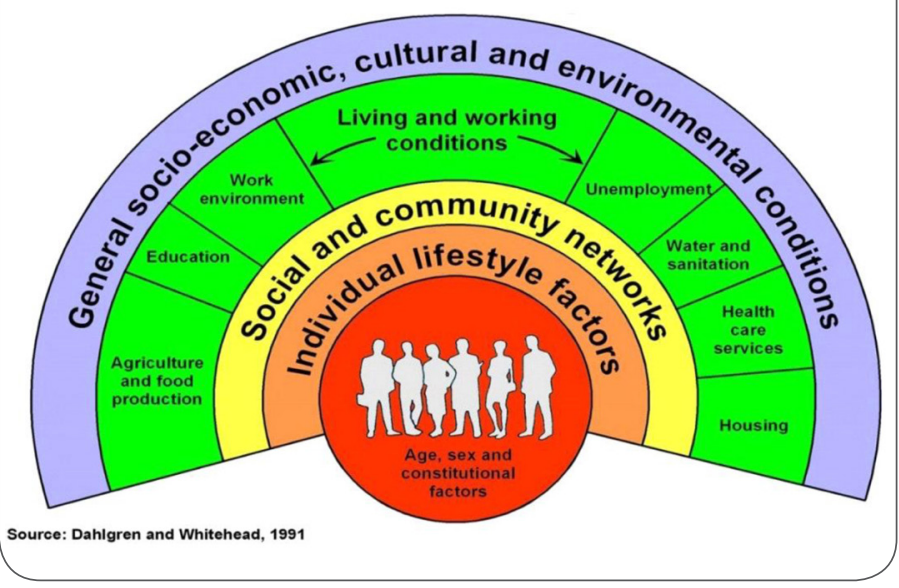

it refers to the social and community relationships that express the level of social cohesion which is of fundamental importance to the health of the population.

The fourth layer analyses conditions of life and work, including the influence of the socioeconomic gradient in health status of individuals. Lastly are the macro determinants that have great influence on other layers and also include supranational determinants $[9,10]$. (Figure 1)

\section{Results and Discussion}

\section{Age, sex and hereditary factors}

This category is the basis of Dahlgren and Whitehead model and it influences on the individual's health conditions [11].

It was observed that the prevalence of GTD cases occurred among women aged between 13 and 19, corresponding to $49.9 \%(n=59)$ of the women analysed. This data confirm others researchers who have found that the occurrence of a molar pregnancy is strongly correlated with maternal age occurring mainly in women under the age of 16 years and above 45 years [12].

Despite not having been evaluated the presence of molar previous pregnancies, Stevens et al [14] argue that the risk of developing GTD gradually increases with the molar amount of previous pregnancies. This information reinforces the influence of genetic factors in the development of this pathology.

Rachad et al [15] argue that the concurrence of several factors, including the high concentration of B-HCG hormone during early pregnancy and the mutation in the receptor gene of the follicle stimulating hormone (FSH) contributes to the development of the GTD.

These aspects are also present in Hyperstimulation Syndrome Ovarian (HSO), which is an adverse effect of ovarian stimulation using medications to increase the FSH in vitro fertilization (IVF) [15]. Seve- 
re HSO presents an estimate to happen in at least $1 \%$ of all gonadotropin cycles and may favour the development of GTD [16].

Controlled ovarian stimulation is a key part of IVF, however when it is held an exogenous administration of low doses of follicle stimulating hormone may occur cancellation of an IVF cycle due to an insufficient response. And when it is held high doses of FSH may also happen cancellation of an IVF cycle due to the risk of hyperstimulation ovarian syndrome. Therefore, it is necessary to know the patient ovarian response, so the gonadotropin doses must be individually adapted to reduce the chances of occurring inappropriate ovarian responses [17].

In vitro fertilization constitutes an expensive procedure and it is not offered by the public health service. Thus, although the procedure is not part of the reality of women studied, the authors considered valid to reinforce the influence of IVF in the incidence of GTD.

\section{Lifestyle of individuals}

This layer refers to the choices taken by individuals which can generate short or long term effects. The suspension of a habit that is detrimental to health will consequently result in a reduction of risk factors and prevention of specific diseases, thus contributing to the maintenance and restoration of health [18].

Despite the only 6 (5\%) women having personal background of smoking and $3.4 \%$ of alcohol consumption, the literature does not mention such habits as risk factors that contribute to the development of GTD.

A total of $69.7 \%(n=83)$ of the participants have not had none previous abortion. This data are corroborated by another study showing that only $19.7 \%$ of molar and $5.4 \%$ of non-molar pregnancies, there was a history of abortion in the last pregnancy [13].

In regard to contraceptive methods used by women, there was prevalence of oral contraceptives with $39(32,8 \%)$ cases, $14(11,8 \%)$ in use of injectable and only $5(4,2 \%)$ has the use of condoms as a choice of contraceptive method. Almasi study [13] confirm this data, which found that $23 \%$ of molar pregnancies and $3.7 \%$ of non-molars were using oral contraceptive pills before pregnancy. So the use of oral contraceptives has been associated with an increased risk for developing this disease (Seckl; Sébire; Berkowitz 2010).

The marital status that prevailed among women was single $(n=50 ; 42 \%)$, followed by married ( $n$ $=33 ; 27,7 \%$ ). However, studies have shown that there is no relationship between the incidence of gestational trophoblastic neoplasia and promiscuity [19].

\section{Social and community Networks}

It is related to family support, colleagues, neighbours and the community. It is called social capital and it has a positive impact on the health status of people [5].

Despite the aspects related to this layer have not been addressed, it was found in the literature data that reinforce the relationship of social and community networks with cancer patients. Several studies found depict the importance of social support as a help in fighting the disease.

The support group has been considered very important for women, once most patients associate the disease with negative feelings. The network of social support, including support groups, helps to cope with the disease and the stages of treatment, also to improve self-esteem [20].

The disease experience is characterized by individual and subjective aspects, ranging from the moment of the diagnosis to the adaptation of the new condition. The feelings of fear and insecurity may hinder this process of adaptation, then it is suggested that these people can count on the support structured by family, friends, work and religion [21]. 


\section{Conditions of life and work}

This layer refers to the conditions of life and work and the availability of food, access to healthy environments and essential services such as health and education. It presents that the socially disadvantaged individuals are differentially exposed to vulnerability and risks health [10].

The education level prevalent among women was less than 8 years $(48.7 \%)$. This low level of education influences the difficulty in entering the labor market and aggravating factors such as the fact that most are adolescents and youth, make the chances of employment even more challenging. Low education can influence both the lack of adherence to self-care and the understanding of the health condition $[22,23]$.

Regarding to occupation, $46(38,7 \%)$ women were housewives, while $26(21,8 \%)$ were students, $12(10,1 \%)$ had as occupation agriculture and 25 $(20,4 \%)$ of the remaining women were in category 'other', with less prevalent occupations. The occupation has a direct impact on monthly income, and understanding that most women did not have a steady job as an occupation, it is possible to infer that low income is a variable that affects these women.

Related to the income, 8 (6.7\%) women indicated have up to 1 minimum wage as income (US\$ 4,020.00 per year). However, this feature cannot be accurately assessed due to lack of information in the medical records. Nevertheless, studies show that low income level makes people opt for foods high in sugar and fat, though cheaper, it has low nutritional value [24].

According exposed by Seckl, Botelho and Ngan $[2,19,25]$, the nutritional deficiency increases the risk of development of GTD. According to Botelho [25], the GTD tends to be less prevalent in developed countries and Ngan [2] shows that the improvement in socioeconomic conditions and diet in some Asian countries, for example, have resulted in a decrease in the number of cases. More specifically
Vitamin A deficiency and decreased beta-carotene intakes are associated with increased risk of developing GTD $[26,27]$.

Most women live on the countryside (60.5\%), a factor that can make difficult the access to health services to early detection of disease, as well as the return to specialized health centre for post-molar follow up.

To be followed by experts after treatment is essential to monitor a possible recurrence or malignant transformation, and for those women who predominantly are on the countryside the access to the return may be more difficult, which may reduce adherence to necessary follow up [28, 29]. Studies show that early detection of the malignant form, followed by appropriate workup, promotes healing of almost all patients with complete preservation of reproductive capacity [30], and improved the patients' quality of life [31].

\section{Economic, Social and Environmental conditions}

The last layer of the model refers to macrodeterminants which have an influence on other layers and it is related to socioeconomic, cultural and environmental conditions of society. It also includes supranational determinants such as the mode of production and consumption of a city, state or country and the process of globalization [32].

Although data collection does not have contemplated aspects related to this layer, the literature shows a relationship between GTD and the economic and social differences to the global level.

It is estimated that the global incidence of GTD is 1:1,000 pregnancies [33]; in Asian countries and Latin America the incidence is three to six times higher than that reported in Europe or North America [34]. In Brazil it is estimated that the disease affects 1: 200-400 pregnancies [29] about five to 10 times more frequent than in North America and Europe [35]. This fact confirms the assumption that women living in underdeveloped or de- 
veloping countries have greater vulnerability to the emergence of GTD.

In Brazil, it is noted that the lack of knowledge about prevention and early detection, lack of access to health services and aspects relating to cultural issues are crucial in maintaining the high incidence of cases of these cancers [36].

The intervention in the health system should seek to reduce the differentials in consequences of the disease, including the improvement of service quality to the whole population, support for the patients, access to rehabilitation care and equitable financing mechanisms, preventing further impoverishment caused by the disease.

The CSDH [37] emphasizes the importance of interventions at the macro, intermediate and micro level about SDH, in order to reduce inequalities related to social stratification, in addition to require a coordinated intersectoral action encompassing various levels of government. It should also be accompanied by more general policies of crosscutting that seek to strengthen the cohesion and expand the "social capital" of vulnerable communities and promote social participation in the design and implementation of policies and programs. Thus, through collaborative intersectoral actions, it is possible to eliminate health inequities to promote the health of the general population.

\section{Conclusions}

Finally, it is understood that GTD has multifactorial aetiology. Despite of the major influence of the genetic factor, the influence of social determinants on health outcomes of these women cannot be neglected.

On the first layer it was found that the most prevalent cases GTD were in patients with extreme age and the presence of genetic factors. Regarding the lifestyle of individuals most women lacked history of smoking and alcohol consumption, most were single and were using OCT. Regarding the Commu- nity networks, the literature provides that support networks are richly effective in fighting the disease for women. Regarding the conditions of living and workingthe majority had less than 8 years of schooling, family income at or below the minimum wage, did not have a steady job and were from the countryside. Regarding macrodeterminants, the literature shows the need for intersectoral action to minimize the inequalities that compromise health and favor the disease process.

Therefore, it is essential for health professionals to understand the individuals in their entirety, considering the various aspects that involve their lives, in order that, by understanding the social determinants of health, they can act effectively in the prevention, early diagnosis, post-discharge treatment and follow-up of GTD.

As study limitation, there is the fact that they were not collected data related to the layers' Community network and support "and for the macrodeterminants, so the discussion was made only on the basis of available literature. Also, the non-fulfillment of important data on the admission form of the records found.

It is suggested that further studies related to the understanding of SDH influence on health outcomes to be made, so that the inequities found to be solved in order to improve care and the population's quality of life through actions to promote proven beneficial health.

\section{Abbreviations}

GTD Gestational Trophoblastic Disease

HP Health Promotion

SDH Social Determinants of Health

BhCG Human Chorionic Gonadotropin

FSH Follicle Stimulating Hormone

HSO Hyperstimulation Syndrome Ovarian

IVF In Vitro Fertilization 


\section{Funding}

All costs relating to the execution of the work and its publication are exclusively responsibility of the authors.

\section{Competing and conflicting Interests}

There is no conflicts of interest related to this work

\section{References}

1. Instituto Nacional do Câncer (INCA). Câncer: o que o câncer? [Internet]. Rio de Janeiro, 2015. Available in: http://www1.inca. gov.br/conteudo_view.asp?id=322.

2. Ngan HYS, Seckl MJ, Berkowitz RS, Xiang Y, Golfier F, Sekharan PK, et al. Figo Cancer Report 2015: Update on the diagnosis and management of gestational trophoblastic disease. International Journal of Gynecology and Obstetrics. 2015; 131: S123-6.

3. Wunsch FV, Antunes JLF, Boing AF, Lorenzi RL. Perspectivas da investigação sobre determinantes sociais em câncer. Physis Rev Saúde Coletiva. 2008: 18(3) 427-50.

4. Brasil. Glossário temático: promoção da saúde. SecretariaExecutiva. Secretaria de Vigilância em Saúde. Ministério da Saúde; 2012.

5. Badziak RPF, Moura VEV. Determinantes sociais da saúde: um conceito para efetivação do direito à saúde. Rev Saúde Pública. 2010; 3(1): 69-79.

6. Dahlgren G, Whitehead M. Policies and Strategies to Promote Social Equity in Health. Stockholm. Sweden: Institute for Futures Studies; 1991.

7. Buss PM, Pellegrini AF. A saúde e seus Determinantes sociais. Rev Saúde Coletiva. 2007; 17(1): 77-93.

8. Geib LTC. Determinantes sociais da saúde do idoso. Ciência \& Saúde Coletiva. 2012; 17(1): 123-33.

9. Brasil. As causas sociais das iniquidades em saúde no Brasil. Relatório final da comissão nacional sobre determinantes sociais da saúde. Comissão Nacional de Determinantes Sociais da Saúde; 2008.

10. Sobral A, Freitas CM. Modelo de organização de indicadores para operacionalização dos determinantes socioambientais da saúde. Saúde Soc São Paulo. 2010; 19(1): 35-47.

11. Souza DO, Silva SEV, Silva NO. Determinantes sociais da saúde: reflexões a partir das raízes da "questão social". Saúde Soc São Paulo. 2013; 22(1): 44-56.
12. Mattei VED, Carnelli L, Bernardi M, Pagani BE, Zucchi P, Lavezzari L, et al. An Investigative Study into Psychological and Fertility Sequelae of Gestational Trophoblastic Disease: The Impact on Patients' Perceived Fertility, Anxiety and Depression. PLoS One. 2015; 10(6): e0128354.

13. Almasi A, Almassinokiani F, Akbari P. Frequency of Molar Pregnancies in Health Care Centers of Tehran, Iran. J Reprod Infertil. 2014; 14(3): 157-60.

14. Stevens FT, Katzorke N, Tempfer C, Kreimer U, Bizjak GI, Fleisch MC, et al. Gestational Trophoblastic Disorders: An Update in 2015. Geburtshilfe Frauenheilkd. 2015; 75(10): 1043-50.

15. Rachad M, Chaara H, Fdili FZ, Bouguern H, Melhouf A. Ovarian hyperstimulation syndrome in a spontaneous pregnancy with invasive mole: report of a case. Pan Afr Med J. 2011; 9: 23.

16. Alper MM, Smith LP, Sills ES. Ovarian hyperstimulation syndrome: current views on pathophysiology, risk factors, prevention, and management. J Exp Clin Assist Reprod. 2009; 6:3.

17. Castro EC, Borges ALF, Rezende KN, Amaral WN. Antral follicle count in predicting appropriate dose of gonatrotropin in vitro fertilization cycles. Reprod Clim. 2014; 29(3): 136-42.

18. Martins AMBB, Zioni F. Comunicação do conhecimento em determinantes sociais de saúde: uma revisão da produção científica. Rev Tempus Actas Saúde Col. 2013; 7(4): 223-38.

19. Seckl MJ, Sebire NJ, Berkowitz RS. Gestational trophoblastic disease. The Lancet. 2010; 376: 717-29.

20. Martins ARB, Ouro TA, Neri M. Compartilhando vivências: contribuição de um grupo de apoio para mulheres com câncer de mama. Rev SBPH. 2015; 18(1): 131-51.

21. Cardoso DH, Muniz RM, Guimarães SRL, Viegas $A C$, Pinto BK, Laroque MF. Viver com câncer: a percepção de pacientes oncológicos. J Nurs Health. 2012; 2(2):462-74.

22. Guimarães AQ, Almeida ME. Os Jovens e o mercado de Trabalho: Evolução e Desafios da Política de Emprego no Brasil. Temas de Administração Pública. 2013; 8(2): 1-26.

23. Silva MAM, Cavalcante AES, Teodósio TBT. Necessidades Psicossociais de uma Gestante Adolescente de Alto Risco Hospitalizada: Estudo de Caso Clínico com Base na Teoria de Wanda Horta. Essentia Sobral. 2014; 16(1): 167-81.

24. Moratoya EE, Carvalhaes GC, Wander AE, Almeida LMMC. Mudanças no padrão de consumo alimentar no Brasil e no mundo. Revista de Política agrícola. 2013; 22(1): 72-84.

25. Botelho NM, Góes ASO, Silva LMG. Aspectos clínicos da doença trofoblástica gestacional. Revista Paraense de Medicina. 2012; 26(3): 1-5.

26. Tse KY, Chan KKL, Tam KF, Ngan HYS. Current management of gestational trophoblastic disease. Obstetrics, Gynaecology and Reproductive Medicine. 2014; 25, (1): 12-21.

27. Hoffman BL, Schorge JO, Halvorson LM, Bradshaw KD, Schaffer $J$, Cunningham FG. Ginecologia de Williams. 1th ed. Mcgraw Hill; 2011. 
28. Guará JP, Oliveira AGC, Martins MG. Neoplasias Trofoblásticas Gestacionais e importância do seguimento pós molar. Rev Pesq Saúde. 2010; 11(3), 50-3.

29. Maestá I, Braga A. Desafios do tratamento de pacientes com doença trofoblástica gestacional. Rev Bras Ginecol Obstet. 2012; 34(4): 143-6.

30. Hoekstra AV, Lurain JR, Rademaker AW, Schink JC. Gestational trophoblastic neoplasia: Treatment outcomes. Obstet Gynecol. 2008; 112(2): 251-8.

31. Ferraz L, Lopes PF, Amim J, Montenegro CAB, Braga A. Atualização no diagnóstico e tratamento da gravidez molar. JBM. 2015; 103(2): 6-12.

32. Pellegrini FA. Intervenções individuais vs. intervenções populacionais. Determinantes sociais da saúde: portal e observatório sobre iniquidades em saúde. 2011 august 16.

33. Cintio ED, Parazzini F, Rosa CC, Hatenoud L, Benzi G. The epidemiology of gestational trofoblastic disease. Gen Diag Pathol. 1997; 143: 103-8.

34. Ozalp SS. Regional perspectives on gestational trophoblastic disease in Turkey. J Reprod Med. 2008; 3: 639-42.

35. Berkowitz RS, Goldstein DP. Current advances in the management of gestational trophoblastic disease. Gynecol Oncol. 2013; 128(1): 3-5.

36. Santos RS, Prates ECPM. Mortalidade e assistência oncológica no Rio de Janeiro: câncer de mama e colo uterino. Esc Anna Nery Rev Enferm. 2011; 15(2): 410-6.

37. Marmot M, Sharon F, Bell R, Houweling TAJ, Taylor S. Social determinants of health inequalities. The Lancet. 2008; 365: 1099-104.

Publish in International Archives of Medicine

International Archives of Medicine is an open access journal publishing articles encompassing all aspects of medical science and clinical practice. IAM is considered a megajournal with independent sections on all areas of medicine. IAM is a really international journal with authors and board members from all around the world. The journal is widely indexed and classified Q1 in category Medicine. 